\title{
Origin of some chemical compounds of a sugarcane wine of Saccharum officinarum Linn from Centreville, Gabon
}

\author{
Abogo Mebale Aimé-Jhustelin, ${ }^{1}$ Ondo Ndong Roger, ${ }^{1}$ Ondo Azi Alain Serge, ${ }^{2}$ \\ Ekome Nguema Marc, ${ }^{1}$ Suebang François Constant, ${ }^{1}$ Ondo Jean Aubin, ${ }^{1}$ \\ Eba François. \\ ${ }^{1}$ Laboratoire Pluridisciplinaire des Sciences (LAPLUS), Ecole Normale Supérieure, B.P. 17009 Libreville, \\ Gabon. \\ ${ }^{2}$ Institut National d'Agronomie et de Biotechnologies (INSAB), Université des Sciences et Techniques de \\ Masuku (USTM). B.P. 905 Franceville, Gabon.
}

\begin{abstract}
The origin of some chemical compounds of sugarcane wine of Saccharum officinarum Linn were studied. The phytochemical analyses showed that alkaloids and tannins come from sugarcane juice and barks of Garcinia sp. The origin of reductor compounds is the sugarcane juice. Flavonoids and saponins come from stem barks of the plant. The $\mathrm{pH}$ of the wine increases when the quantity of barks increases.

Keywords: Phytochemical compounds, sugarcane wine, Garcinia sp, Saccharum officinarum Linn.
\end{abstract}

\section{Introduction}

The sugarcane wine is a traditional alcoholic drink produced from fermentation of sugarcane juice of Saccharum officinarum in the presence of barks of Garcinia sp [1]. Since many years, the commercialization of this wine increase and lead to the improvement of the living conditions of many families [2]. The recent studies showed that the sugarcane wine content alkaloids, polyphenols, tannins, reductor compounds and flavonoids [3]. A lot of these compounds are benefit of the health of human being. Alkaloids and flavonoids have antioxidant and antidiabetic properties [4-6]. The origin of some chemical constituents of sugarcane wine is not establish. This paper show with certainty different origins of alkaloids, flavonoids, saponins, tannins and reductor compounds contained in the sugarcane wine and the evolution of $\mathrm{pH}$ when quantity of bark increase.

Sugarcane juice

\section{Materials And Methods}

Mature Saccharum officinarum Linn was collected in village Centreville (north of Gabon) in January 2014. The juice was extracted using a manually sugarcane press. $750 \mathrm{~mL}$ of the juice is left for two weeks at room temperature in the presence of the air.

\section{Sugarcane wine preparation}

To be fermented to become sugarcane wine, the juice $(750 \mathrm{~mL})$ was put in the plastic container and stem barks of Garcinia sp was added $(50 \mathrm{~g})$. The mixture is left for two weeks at room temperature in the presence of the air.

\section{Stem barks extract}

$50 \mathrm{~g}$ of stem barks of Garcinia sp and $750 \mathrm{~mL}$ of distilled water was added to the plastic container. The mixture is left for two weeks at room temperature in the presence of the air.

\section{Phytochemical analysis}

Chemical constituents were determined using the methods described by Harborne, Hegnauer and Wagner [7-9].

Tests of flavonoids were realised using the aqueous solutions of $\mathrm{NaOH}$ at $10 \%$ and $\mathrm{FeCl}_{3}$ at $2 \%$. Alkaloids were characterized by the marketing Dragendorf reagent. Tannins were analysed by aqueous solution of lead acetate at $10 \%$. Test of reductor compounds was done with the marketing Fehling reagent. Test of saponins was realised by observation of persistent foam (up to1 $\mathrm{cm}$ ) during $15 \mathrm{~min}$. after shaking the extract in a test tube.

$\mathrm{pH}$

The $\mathrm{pH}$ of sugarcane wine was measured after 7 days $\left(\mathrm{pH}_{1}\right), 14$ days $\left(\mathrm{pH}_{2}\right)$ and 21 days $\left(\mathrm{pH}_{3}\right)$, using the $\mathrm{pH}$-meter Lutron $\mathrm{pH}-201$. The $\mathrm{pH}_{0}$ of the freshly sugarcane juice was 4.45 . 


\section{Results And Discussion}

Phytochemical analyses of sample of sugarcane wine showed the presence of alkaloids, tannins, reductor compounds, saponins and flavonoids (Table 1). Results were qualitatively expressed as negative (-) or positive (+).

Alkaloids, flavonoids, tannins and saponins are present in the stem bark extract. However, reductor compounds were not found. The sugarcane juice contents alkaloids, tannins and reductor compounds but saponins and flavonoids were not found.

The results of the Table 1 show that alkaloids and tannins come from barks and sugarcane juice. Barks of Garcinia sp are the only origin of flavonoids and saponins. Reductor compounds come from sugarcane juice.

The effects of sugarcanewine may be due to the presence of alcohol and alkaloids. Indeed, some alkaloids, such as cocaine, have euphoric properties [10]. Tannins are often combined with alkaloids. It is perhaps for this reason that both are found in cane juice and barks extract. Flavonoids are water soluble phenolic compounds. They diffuse easily by soaking in the juice. The disappearance of saponins over time shows that these compounds are not very stable. The anti-diabetic effect of the sugarcanewine could be limited [11]. The presence of tannins gives the wine the ability to precipitate heavy metals [12]. But, some of them, can be dangerous for the human health.

Table 2 shows that the $\mathrm{pH}$ increases when the amount of barks increases. Indeed, after seven days the $\mathrm{pH}$ is 3.46 for juice without barks, 3.7 when the juice contains 50 grams of barks and 4.08 when there is $100 \mathrm{~g}$ of barks in the wine. This trend was observed at 14 days and 21 days (Figure 1). The $\mathrm{pH}$ increase may be explained by the presence of more alkaloids which are basic compounds [13].

In sugarcane juice without barks, $\mathrm{pH}$ gradually decreases from 4.45 to 3.02 after 21 days (Figure 2). This decrease can be attributed to the progressive formation of the acetic acid.

In the presence of barks, the $\mathrm{pH}$ tends to decrease after 14 days and to increase after 21 days. The alcoholic fermentation may be the cause of the decrease in $\mathrm{pH}$. But it rises after 21 days because of the presence of a larger amount of alkali compounds [13].

\section{Figures And Tables}

Table 1. Results of phytochemical screening

\begin{tabular}{|l|c|c|c|}
\hline Chemical constituents & Stem bark extract & Sugarcane juice & Sugarcane wine \\
\hline Flavonoids & + & - & + \\
\hline Alkaloids & + & + & + \\
\hline Tannins & + & + & + \\
\hline Reductor compounds & - & + & + \\
\hline Saponins & + & - & + \\
\hline
\end{tabular}

Table 2. $\mathrm{pH}$ of sugarcane wine

\begin{tabular}{|c|c|c|c|c|}
\hline Weigth of bark (g) & $\mathbf{p H}_{\mathbf{0}}$ & $\mathbf{p H}_{\mathbf{1}}$ & $\mathbf{p H}_{\mathbf{2}}$ & $\mathbf{p H}_{\mathbf{3}}$ \\
\hline 0 & 4.45 & 3.46 & 3.13 & 3.02 \\
\hline 50 & 4.45 & 3.70 & 3.53 & 3.66 \\
\hline 100 & 4.45 & 4.08 & 3.70 & 3.90 \\
\hline
\end{tabular}

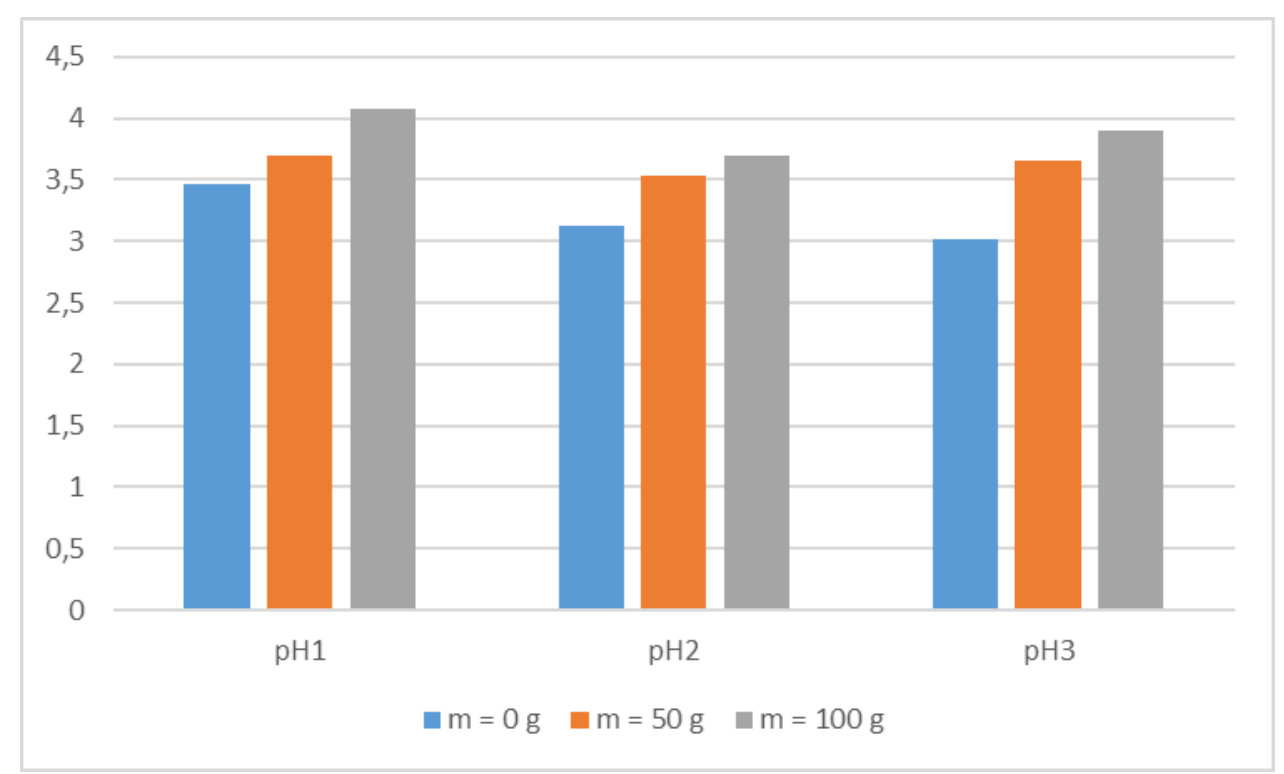

Figure 1. Evolution of the $\mathrm{pH}$ of the sugarcane wine. 


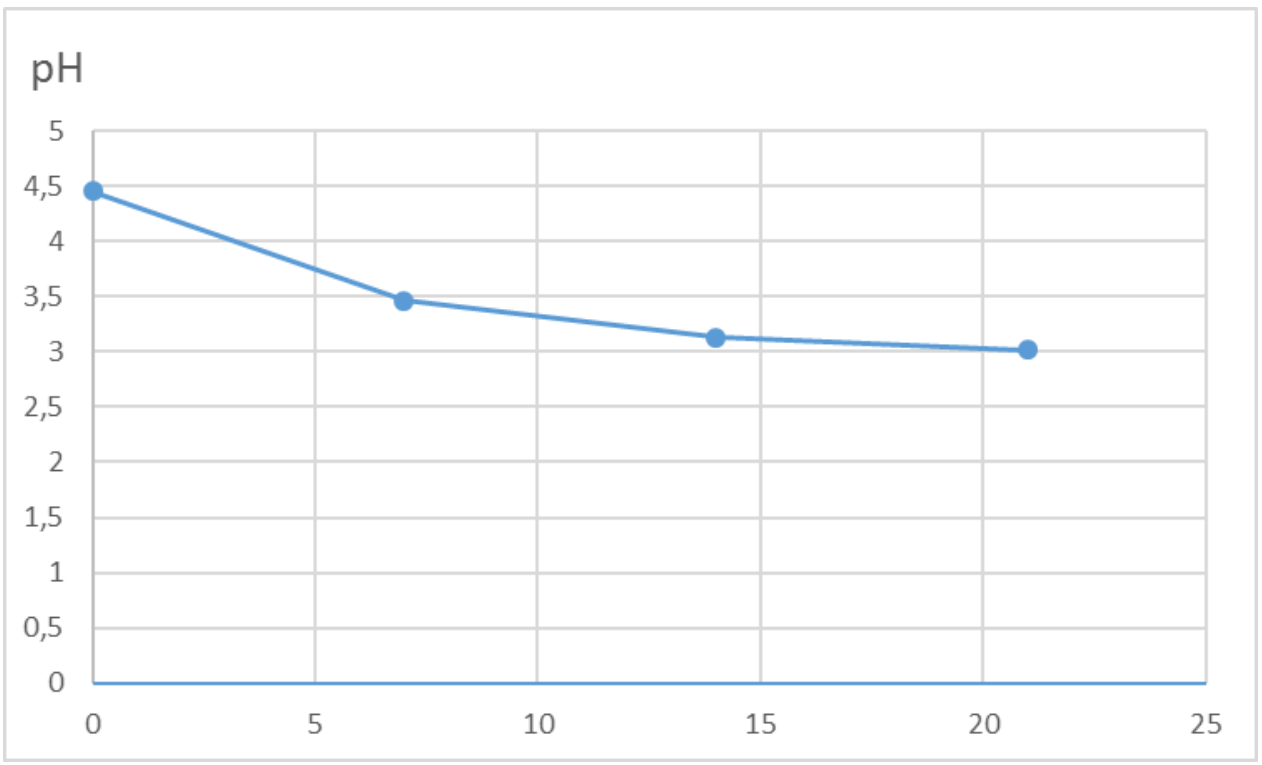

Figure 2. Evolution of the $\mathrm{pH}$ of the sugarcane juice.

\section{Conclusion}

In this paper, we reported the more important results obtained for the studies of phytochemical analyses and alcohol level of sugarcane wine of Saccharum officinarum Linn. The origin of some chemical compounds of sugarcane wine was determined. Alkaloids and tannins come from sugarcane juice and barks of Garcinia sp. The origin of reductor compounds is the sugarcane juice. Flavonoids and saponins come from stem barks of the plant. The $\mathrm{pH}$ study showed that bars of barks contain basic compounds which diffuse in the wine.

\section{References}

[1] A. Raponda-Walker and R. Sillans. Les plantes utiles du Gabon. Fondation Raponda-Walker. Edition Sépia. 1995; 197-198.

[2] N. Luzietoso, P.C. Bom Khonde, J.J.M. Bazabana. Utilisation, transmission et amélioration d'un savoir-faire traditionel: le cas du vin de canne à sucre. Notes CA. $2000 ; 24,1-4$

[3] A.J. Abogo Mebale, F.C. Suébang, A.S. Ondo Azi, J.N. Yemelong, J.A. Ondo, E. Nsi Emvo, F. Eba. Chemical composition of a standard sugarcane wine of Saccharum officinarum Linn from Woleu-Ntem, Gabon. Journal of Agriculture and Sustainability. Vol.3 (2); 216-222.

[4] B.H. Havsteen. The biochemistry and medical significance of the flavonoids. Pharmacol. Therapeutics. 2002; 96, 67-202.

[5] A.P. Bidié, B.B. N'guessan, A.F. Yapo, J.D. N'guessan and A.J. Djaman. Activités antioxydantes de dix plantes medicinales de la pharmacopée ivoirienne. Sciences \&Nature. 2013. Vol 8(1-2); 1-12.

[6] A. Meddour, M. Yahia, N. Benkiki and A. Ayachi. Etude de l'activité antioxydante et antibactérienne des extraits d'ensemble des parties des la fleur du Capparis spinosa L. Lebanese Science Journal. 2011. Vol 14 (1); 49-60.

[7] J.B. Harborne. Phytochemical Methods ; A guide to modern techniques of plant analysis $2^{\text {nd }}$ Edition, London New York. 1973.

[8] R. Hegnauer. Chemotaxonomie der Pflanzen, Bikhaäuser Verlag, Basel, Suttgart, 6. 1973; 761.

[9] H. Wagner. Drogen analyse, Dünschicht chromatographische Analyse von Arzneidrogen. Springer Verlag Berlin Heidelberg New York. $1983 ; 522$

[10] T. Aniszewki. Alkaloids- Secrets of life. Alkaloid Chemistry, Biological Significance, Applications and Ecological Role. Elsevier first Edition 2007.

[11] O. Nacoulma-Ouédraogo. Plantes médicinales et pratiques médicinales traditionnelles au Burkina Faso : cas du Plateau central. Thèse de Doctorat ès Sciences Naturelles, Université de Ouagadougou (Burkina Faso). 1996.

[12] E.S.I. Atefeibu. Contribution à l'étude des tanins et l'activité antibactérienne de Acacia nilotica var adansonii.Thèse de doctorat en pharmacie. Université Cheikh Anta Diop de Dakar (Sénégal ) 2002.

[13] J. Bruneton. Pharmacognosie, phytochimie, Plantes médicinales. Paris 4ème édition Lavoisier. 2007. 